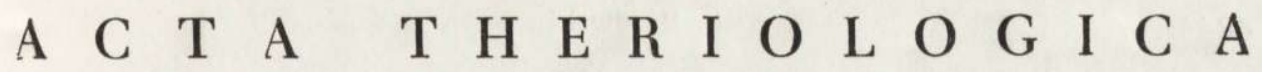 \\ VOL. XIII, 30: 483-498. \\ BIAEOWIEŻA \\ 28.XII.1968
}

\author{
Stanisław B O R O W S K I
}

\section{On the Moult in the Common Shrew}

[With 3 Figs., 2 Tab. \& Plate XIV]

\begin{abstract}
On the basis of a large material $(n=905)$ obtained during the spring months (March-June, 1953-1964) it was shown that the common shrew, Sorex araneus L in na e us, 1758 exhibits two spring moults, differing in character and the time and direction in which they proceed. Spring moult I consists in change from the 6-segment winter hair to the 5-segment spring hair, and proceeds from the ventral side of the body to the back. The second, spring moult II, changes the spring hair to the 4-segment summer hair and begins on the back and ends on the ventral side of the animal. Interrupted moults were observed in a fairly large percentage of the of the individuals in a population: the first in $40 \%$, the second in $22 \%$. Both changes of coat may take the form of total moult or of wave moult. Spring moult I begins in the Białowieża Primaeval Forest during the second ten-day period of March, and in principle ends during the last ten days of April. Spring moult II does not in fact begin until the last ten-days of April and lasts to the first ten-day period of June. Males moult earlier than females. Changes in skin thickness, and length of hair in different seasons, and also earlier observations of captive animals, indirectly permit of the assumption that in the spring shrews may in some cases change the 6 -segment winter hair for secondary winter hair of the same length.
\end{abstract}

\section{INTRODUCTION}

Many authors, in describing the spring moult in Soricidae ( $\mathrm{J}$ a cks on, 1928; Ognev, 1928; Dehnel, 1949, 1950; Findlay \& J ones, 1956; M e e s ter, 1958 and others) have mentioned the waves of long and short hair following upon each other in a specific way in different places on the mammal's body. It is characteristic of these studies that the above authors, in discussing the spring moult, do not refer to the changes taking place in the skin (blackening), despite the fact that they emphasises the existence of this phenomenonon during the autumn moult. All of them are unanimous in stating that the autumn moult begins in the sacral region and proceeds in a forward direction, gradually descending to the ventral side of the body. The spring moult, on the other hand, begins with the head and proceeds in a direction towards the tail and ventral side of the body. Other authors (Popov, 1960; Sk aré n, 1964) state that the spring moult in the common shrew takes the reverse course, i.e. begins on the ventral side and ends on the dorsal side. 
The fact that changes were not observed in the skin in the spring led to the formation of the hypothesis hitherto put forward, that in Soricidae of the genera Sorex and Neomys normal moult does not take place in the spring at Bialowieża, but that the hair becomes shorter by means of "reduction " (B orowski, 1952). This report was based on a large amount of systematically collected material (about 5000 individuals over a period of six years). Although this material might appear to be representative, it contained only 247 individuals from the spring months (March-May) in which the true moult accompanied by changes in the skin was not found (reinspection of this material revealed that one individual from the first ten days of April 1948 was in the initial phase of the moult and had only faintly visible changes in the skin round the lateral glands).

It was then clear that waves of short and long hair progress twice over the animal's body, once from the ventral side on to the back, and soon after this from the back to the ventral side. These directions thus correspond to the changes in the coat observed in spring by all the above-mentioned authors, and termed by them moult.

The course taken by the autumn moult in young individuals and the senile moult in old adults formed the object of earlier studies (D e h n e l, 1949; B o r o v$\mathrm{sk} \mathrm{i,} \mathrm{1952,} \mathrm{1963).}$

The aim of this study is to analyse once again the spring change in the coat in the common shrew and to review the earlier contradictory views held on this question.

\section{MATERIALS AND METHODS}

Very few captures are made on permanent trapping areas (D e h n e 1, 1949; B orowski \& Dehnel, 1953) during winter, early spring and spring in comparison with summer collections of material. As from February 1953 additional trappings were therefore made in the Białowieża National Park, using live-traps and snap-traps with bait, situated in places where the shrews were likely to pass. In addition traps and metal cylinders (= pitfalls) were also placed in specially dug trenches of different length, measuring $30 \times 30 \mathrm{~cm}$ in the cross-section, and covered with branches.

The variety of trapping methods used produced a relatively large amount of spring material $(n=905)$ during the period 1953-1964 (Table 1). The materal used in this study consisted of flat skins and specimens preserved in alcohol. The condition of the shrews' coats at the end of February of each year was also checked.

The changes taking place in the skin, the appearance and disappearance of black pigment, with simultaneously occurring changes in thickness of the skin and different length of hairs, were taken as the criterion of the moult. In orcer to distinguish the winter hair from spring and summer hair the number of segments of the hair on each skin were counted under a binocular microscope, mairly on the dorsal side of the body, or on both sides of the boundary between short and long hair, in cases of interrupted moult. The thickness of the skin was cetermined using sections also taken from the dorsal region on the scapulae. Cur reason for this was the statement made by Cerevitinov (1958) that we are concerned with a hair covering of the sacrodorsal type in the case of shrews, $i e$. that the length of the hair decreases from back to belly, and thus it was a question of obtaining comparable results. Measurements of the thickness of the skin, 


\begin{tabular}{|c|c|c|c|c|c|c|c|c|c|}
\hline \multirow{3}{*}{ 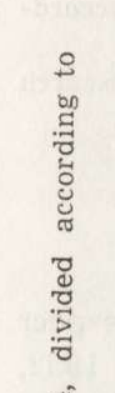 } & \multicolumn{3}{|c|}{ 귱 } & $\because$ & 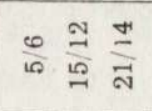 & 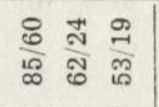 & 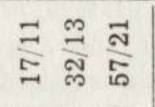 & 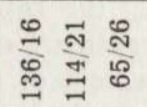 & 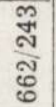 \\
\hline & \multicolumn{3}{|c|}{ 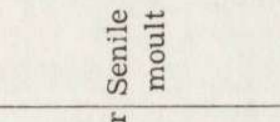 } & $\Xi$ & & $\frac{0}{4}$ & ํㅣㅇ & 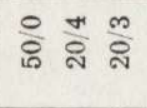 & $\underset{\mathscr{\varpi}}{\stackrel{7}{*}}$ \\
\hline & \multicolumn{3}{|c|}{ 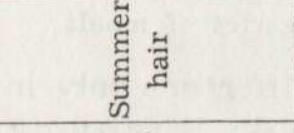 } & $\dddot{m}$ & & $\frac{-1}{0}$ & $\stackrel{m}{\vec{J}} \overrightarrow{\bar{N}}$ & 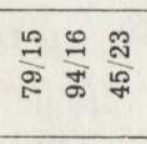 & 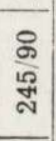 \\
\hline \multirow{3}{*}{ 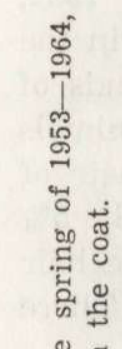 } & \multicolumn{3}{|c|}{ 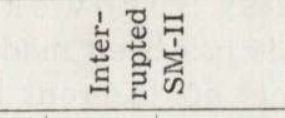 } & શ & & & 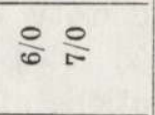 & 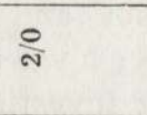 & $\stackrel{0}{20}$ \\
\hline & \multirow{3}{*}{ 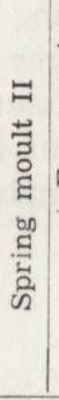 } & \multirow{2}{*}{ 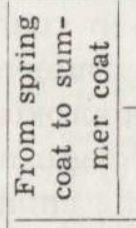 } & $\sum_{\substack{0 \\
3}}^{0}$ & $=$ & & $\stackrel{\circ}{=}$ & $\stackrel{0}{\circ} \div$ & $\stackrel{0}{-}$ & $\stackrel{\circ}{6}$ \\
\hline & & & సี & 익 & & $\stackrel{0}{-1}$ & $\stackrel{\circ}{m} \stackrel{0}{9}$ & $\stackrel{0}{=}$ & $\stackrel{\circ}{m}$ \\
\hline 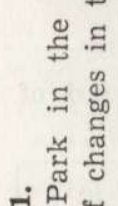 & & \multicolumn{2}{|c|}{ 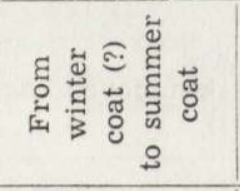 } & $\infty$ & & $\frac{1}{0} \frac{N}{m}$ & $\frac{m}{\pi} \stackrel{-1}{-}$ & & $\stackrel{\infty}{\infty}$ \\
\hline \multirow{6}{*}{ 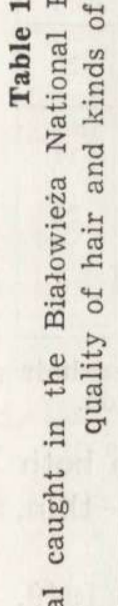 } & \multicolumn{3}{|c|}{ 章. } & $\infty$ & $\stackrel{\circ}{\text { ก }}$ & 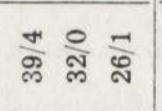 & ำำ & $\vec{m}$ & $\stackrel{5}{\frac{5}{6}}$ \\
\hline & \multicolumn{3}{|c|}{ 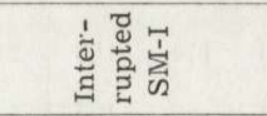 } & - & & $\stackrel{0}{10}=$ & & & $\varlimsup_{5}^{\infty}$ \\
\hline & \multirow{5}{*}{ 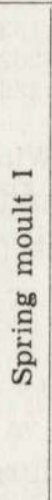 } & \multirow{2}{*}{ 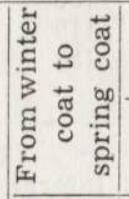 } & $\begin{array}{l}\pi \\
\frac{\pi}{3} \\
3\end{array}$ & $\infty$ & $\stackrel{\circ}{\infty}$ & $\frac{10}{2}=5$ & & & 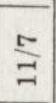 \\
\hline & & & 嵒 & is & $\stackrel{0}{4}$ & $\frac{2}{\pi}=\frac{0}{2}$ & $\stackrel{0}{-}$ & & $\stackrel{\circ}{6}$ \\
\hline & & \multirow{3}{*}{ 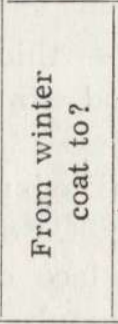 } & $\underset{+1}{\tilde{D}}$ & $\omega$ & 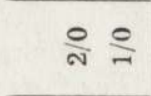 & $\stackrel{N}{=} \frac{\pi}{m}$ & & & $\stackrel{\infty}{5}$ \\
\hline & & & 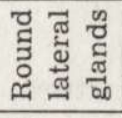 & $\infty$ & $\stackrel{0}{\div} \stackrel{0}{\text { ก }}$ & $\div \div$ & & & $\stackrel{0}{10}$ \\
\hline 离 & & & 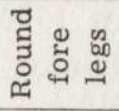 & N & $\stackrel{\circ}{\rightarrow}$ & $\frac{\pi}{2} \overline{0}$ & & & $\stackrel{0}{\check{1}}$ \\
\hline 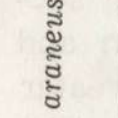 & \multicolumn{3}{|c|}{ 苛 } & -1 & 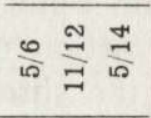 & 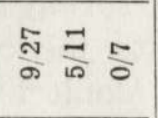 & $\frac{0}{\mathrm{~N}}$ & & 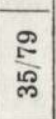 \\
\hline \multirow{3}{*}{ ถัँ } & \multicolumn{4}{|c|}{ pọt..аd Kep-uәL } & カコヨ & ー日コ & サコヨ & カヨ日 & 可 \\
\hline & \multicolumn{4}{|c|}{ чрuоN } & ЧЈ.еल & I!..dV & ${ }_{*}{ }_{\mathrm{S}}^{\mathrm{B}} \mathrm{\textrm {NI }}$ & *aun $\rho$ & $\stackrel{\circ}{*}$ \\
\hline & \multicolumn{4}{|c|}{ po!̣. } & & 00 & $796 \mathrm{I}-896$ & & \\
\hline
\end{tabular}


including the reticular layer, were made on microscopic sections prepared according to standard methods.

The whole of the evidential material is to be found in the Mammals Research Institute of the Polish Academy of Sciences at Białowieża.

\section{RESULTS}

\section{Length of hair, thickness of skin, eategories of moult}

The various categories of the shrew's coat differ not only in respect of colour and density of hairs (Dehnel, 1949; Borowski, 1952, 1959; S c hw a r z, 1955) but also length. Analysis has been made in the present investigations of the number of segments of different kinds of summer, spring and winter hair, and thickness of skin in young animals and old adults. It can be seen from table 2 that the summer hair of young individuals usually has 4 segments, and only approximately $5 \%$ of the hairs consist of 5 segments. In old adults the length of the hair in the summer coat is slightly lesser than that in young animals. There

Table 2.

Variability of hair length and average thickness of skin depending on kind of fur and age of shrews.

\begin{tabular}{|c|c|c|c|c|c|c|c|c|}
\hline \multirow{2}{*}{ Kind of fur } & \multirow{2}{*}{ Age } & \multirow{2}{*}{ Caught in: } & \multicolumn{2}{|c|}{ Length of hairs* } & \multicolumn{4}{|c|}{ Thickness of skin in $\mu$} \\
\hline & & & $\begin{array}{c}\text { No. of } \\
\text { segments }\end{array}$ & $\mathrm{mm}$ & Min. & Avg. & Max. & $\mathrm{N}$ \\
\hline $\begin{array}{l}\text { Summer } \\
\text { Winter }\end{array}$ & $\begin{array}{l}\text { Young ad. } \\
\text { Young ad. }\end{array}$ & $\begin{array}{l}\text { June, Oct. } \\
\text { Oct., Jan., }\end{array}$ & $4(5)$ & $3.0-4.0$ & 114 & 155 & 213 & 11 \\
\hline & & March & 6 & $6.0-7.2$ & 69 & 105 & 147 & 20 \\
\hline Winter ** & Sub.-ad. & April & & $6.0-7.2$ & 82 & 119 & 193 & 9 \\
\hline Spring & Old ad. & April & & $4.8-5.7$ & 123 & 152 & 202 & 7 \\
\hline Summer & Old ad. & May & $4(3)$ & $3.0-3.5$ & 166 & - & 226 & 2 \\
\hline
\end{tabular}

* - Measurements from 10 specimens of each kind of fur. ** - Winter hair on back with beginning of SM-I in inguinal region and round lateral glands.

are in principle two kinds of thickness of skin: summer - thick (in both young animals and old adults) from $114-213 \mu$ thick, and winter - thin, $69-147 \mu$ thick (Table 2).

It is clear from data hitherto given in literature (Dehnel, 1949, 1950; Borowski \& Dehnel, 1953; Stein, 1954; Crowcroft, 1955, 1957; Skaré $\mathrm{n}, 1964)$ that three moults take place during the shrew's life: the autumn, spring and senile (old-age) moults. The successive moults differ as to the direction of changes in the skin and growth of the new hair. Moult in the shrew may include the greater part or the whole of the animal's skin »complete " moult (Photo 1, Fig. $1-\mathrm{A}, \mathrm{C}, \mathrm{F}$ ), or takes place only within a narrow band of skin, $1-5 \mathrm{~mm}$ wide - the "wave" moult (Photo 2, Fig. 1 - B, D, G). 


\section{Spring moult}

A detailed analysis of material obtained during the spring months (March-June) from 1953-1964 (cf. Table 1) justified the statement that the change from winter to summer hair does not take place directly. Two stages are clearly defined, differing from each other as to the character of change in length of the hair, direction of the course taken by the moult and the time at which it occurs. Both stages are two normal moults following one upon the other, which I term the spring moult I (SM-I) and spring moult II (SM-II). In both moults the change of hair may take place over the whole of the animal's body, or large parts of it, or in waves. Intervals in moulting are also frequently found, and in such cases the shrews had long hair on one part of the body, and short in another, without any changes in pigmentation of the skin. As, however, we know the length of the hairs and number of segments of hairs in different kinds of fur, all the specimens (even those in interrupted moult) could be allocated to one of the above-mentioned types of moult.

\subsection{Spring moult I}

The first spring moult in shrews leads to a change from the 6-segment winter hair to the 5 -segment spring hair.

SM-I in the total form begins in the inguinal region and progresses along the belly to the front of the body. It next proceeds to the flanks and outer side of the thighs, passes to the sacro-lumbar region and the head, then spreads along the dorsal side, where it most often ends (Fig. $1 \mathrm{C}$, Photo 1). The wave SM-I takes a similar course (Fig. $1 \mathrm{D}$, Photo 2). Individuals of $S$. araneus are, however, encountered in which the moult, after the change of coat on the belly, passes to the dorsal side only in the anterior part of the body. In such cases it progresses along the flanks and the back towards the tail. It is then possible to observe a wave of shorter - spring and longer - winter hair running transversely to the trunk of the animal's body (Photo 3).

Intervals in moulting were observed in a relatively large number of individuals during the change from winter to spring coat (Table 1 colum 7). Such animals, with short and long hair on light-coloured skin, were found in each phase of the change of coat. It is, however, the wave moult which is subject to interruption, when the pigment of the skin gradually disappears along a narrow band and the animal remains for a time with tufts of long winter hair. In the case of captive animals these intervals were found to last for as long as $2-3$ weeks. It is difficult to give any definite statement on the reason of this facts. 


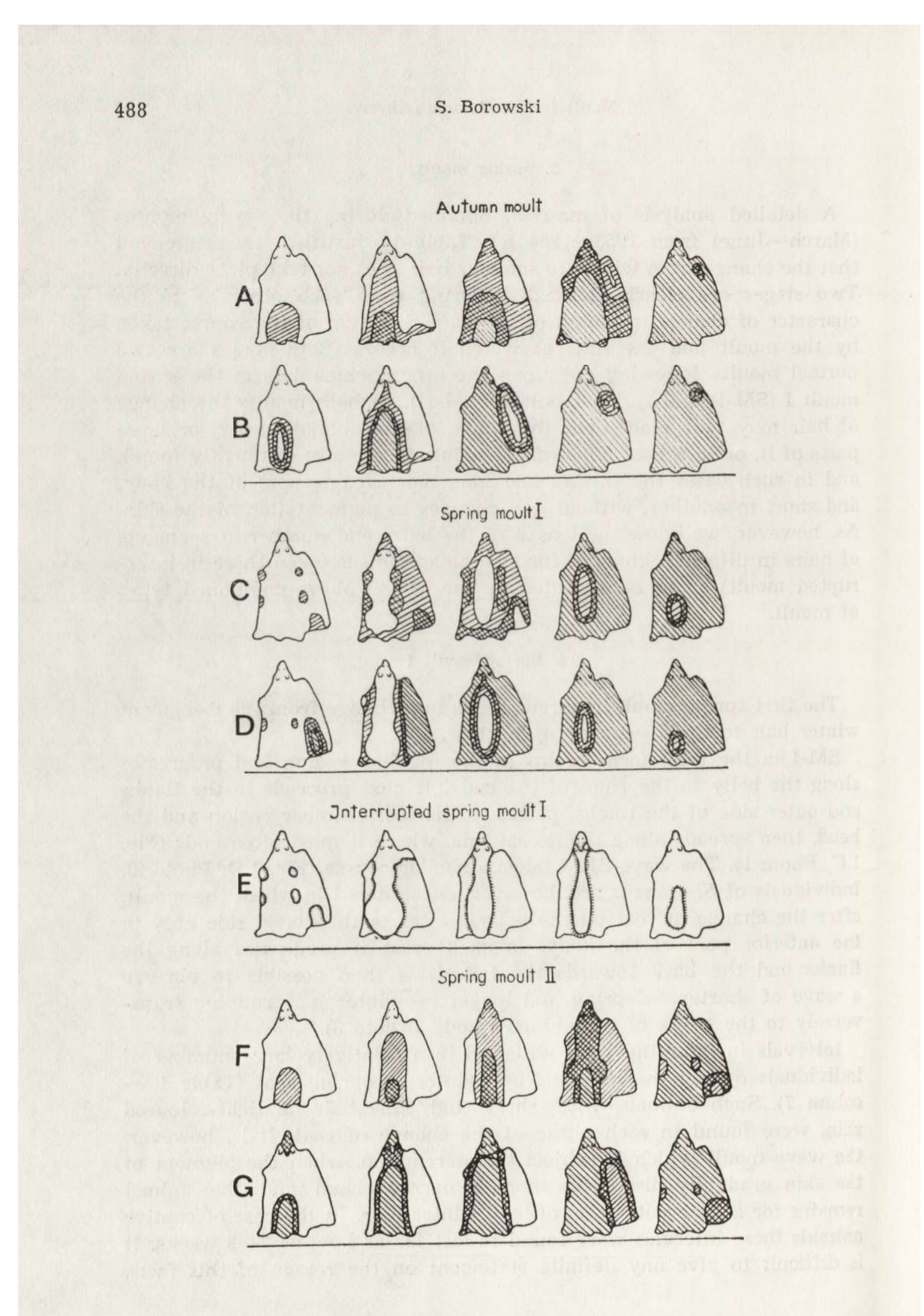




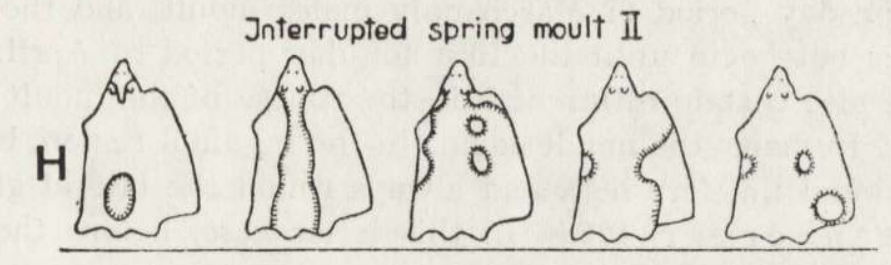

\begin{tabular}{|c|c|c|c|c|c|}
\hline \multirow{2}{*}{\multicolumn{3}{|c|}{ Skin $A-G$}} & \multicolumn{3}{|c|}{ Fur } \\
\hline & & & $A-B$ & $C-D$ & $F-G$ \\
\hline QDIDID & $\begin{array}{l}1 \\
2 \\
3 \\
4\end{array}$ & $\begin{array}{l}\text { Light } \\
\text { Dark } \\
\text { Dark } \\
\text { Light }\end{array}$ & $\begin{array}{l}\text { Summer } \\
\text { Summer } \\
\text { Winter } \\
\text { Winter }\end{array}$ & $\begin{array}{l}\text { Winter } \\
\text { Winter } \\
\text { Spring } \\
\text { Spring }\end{array}$ & $\begin{array}{l}\text { Spring } \\
\text { Spring } \\
\text { Summer } \\
\text { Summer }\end{array}$ \\
\hline
\end{tabular}

Fig. 1. Diagram of successive phases of change of coat in Sorex araneus. A, C, F - total moult; B, D, G - wave moult; E, H - successive stages of intervals in moulting. The strokes on the continuous line point in the direction of the new hair.

After a certain time the moult begins again and complete change of hair takes place on those parts of the body on which the long winter hair had remained.

The first moult begins with $S$. araneus in the second 10-days period of March and usually ends during the last ten days of April. It proceeds most intensively in the last ten days of March and first ten days of April, when it affects respectively $40 \%$ and $32 \%$ of all the individuals. During the remaining period it affects approximately $15 \%$ of the individuals (Fig. 2).

One case of moulting as late as the first ten days of May was observed (Table 1, column 5). The skin on flanks and belly was light in colour, with spring hair, sharply differentiated from the back, where then skin was black and covered with winter hair. It may therefore be assumed that the interrupted first moult had been renewed in this individual.

The spring moult in shrews occurs during the reproduction period, when the sex ratio in the material obtained from captures on permanent trapping areas is seriously disturbed (cf. P u cek, 1959). The absolute numbers of moulting individuals of both sexes in different 10 day periods are not therefore conclusive in explaining the differences in the moulting of males and females. Some regularities can, however, be seen in table 1. Males begin moulting earlier than females. In the second 
and third ten-day period of March only males moult, and the SM-I of females does not begin until the first ten-day period of April.

There are also certain differences in the course of the moult in males and females. In males the moult begins in the inguinal region, but sometimes also round the fore legs, and always round the lateral glands (cf. also Spitzenberger, 1966). In this latter case, before the specific

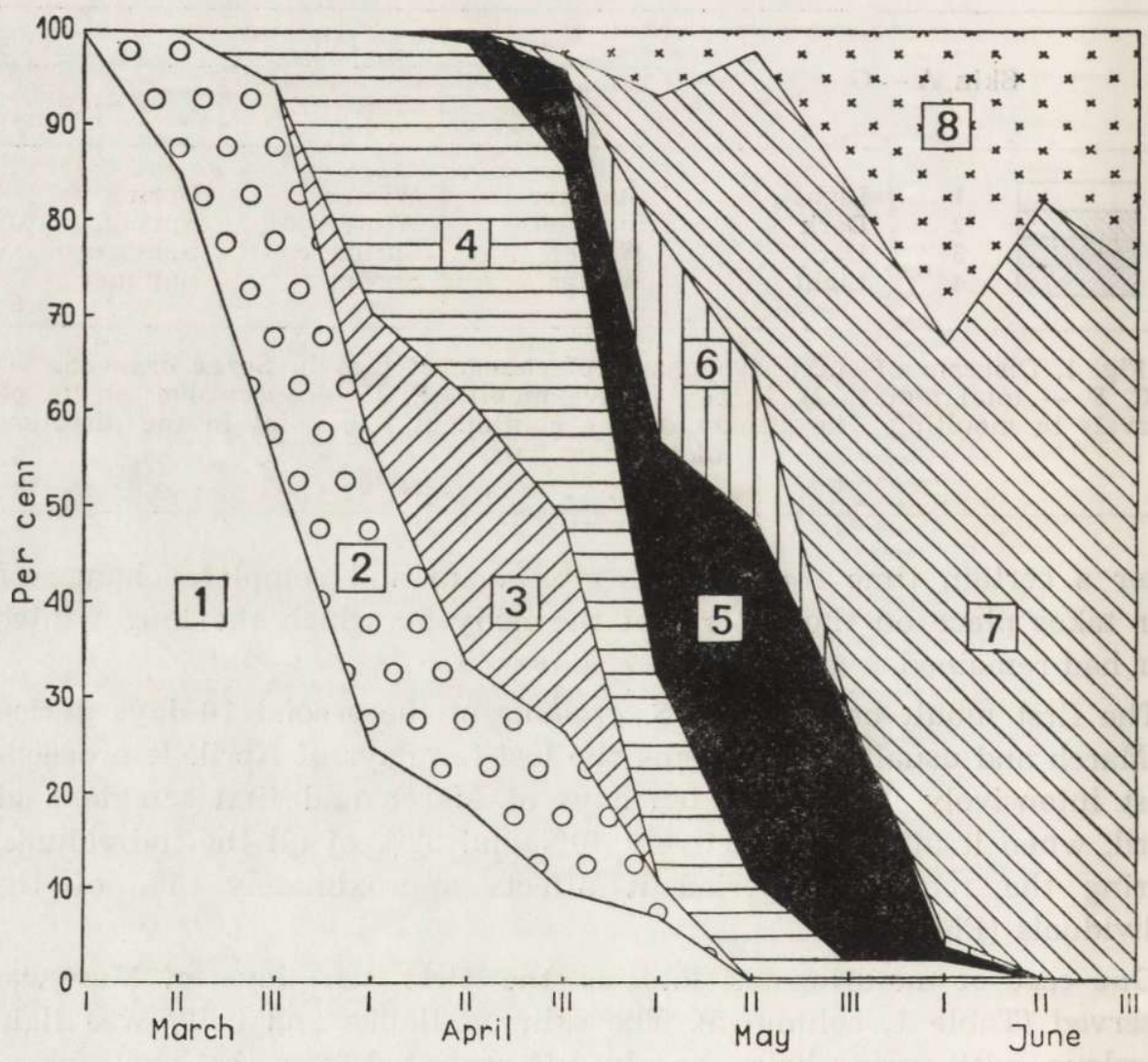

Fig. 2. Course taken by spring change of coat in the common shrew from 1953$1964\left(\mathrm{n}=905, \sigma^{*} \sigma^{*}+\right.$ 우 $)$. Percentage of individuals in ten-day period samples with given kind of coat, or passing through a given phase of moulting. 1 - Winter hair. 2 - Spring moult I. 3 - Interval in spring moult I. 4 - Spring hair. 5 - Spring moult II. 6 - Interval in spring moult II. 7 - Summer hair. 8 - Senile moult.

roll of hair grows on the gland (Dehnel, 1949) the coat round it changes from winter to spring (3rd ten-day period of March). This change takes place on an elliptic area measuring $5 \times 10 \mathrm{~mm}$ and is very often interrupted, like that round the fore legs (Fig. $1 \mathrm{E}$ ). When the moult is renewed these places remain unchanged. 
The females do not change the hair round the lateral glands. During sexual maturescence the skin thicknes in this area, as in males, but after 3-4 days this thickening disappears, leaving only a yellow trace scarcely visible to the naked eye. Moult round the fore legs takes place about four times more often than in males (Table 1, column 2).

The interrupted first spring moult in the case of all shrews takes place only in April, and in about $21 \%$ of the individuals from that month (Fig. 2). The homogeneous spring coat is already present in animals caught in the third ten-day period of March (6\%), practically up to the second ten-day period of May $(11 \%)$, although single individuals with such hair are also found at the the end of May and first half of June (Fig. 2).

\subsection{Spring moult II}

Spring moult II consists in principle in the change from the 5-segment spring hair to the 4-segment summer hair. The direction taken by this moult is exactly opposite to SM-I. It begins in the sacral region and on the head, descending ventrad down the flanks. SM-II ends in the inguinal region, and in the case of males, also near the lateral glands (Fig. $1 \mathrm{~F}$ ). As the moult takes place over the greater parts of the body the start of blackening of the skin can be seen in the sacral region and on the shoulders. If the moult takes place in waves it may begin on the head only, or simultaneously on the head and sacral region (cf. D e h$\mathrm{n}$ el, 1949). It can be seen from the above that the course taken by SM-II is similar to that of the autumn moult. The latter, however, ends on the throat (Fig. 1 A, B).

SM-II is also subject to interruption. Among all the individuals changing spring to summer hair it was found that no changes in the skin (blackening) occurred in $22 \%$ of the individuals, and that there was spring hair on one part of the body and summer hair on another. We observed all possible stages of change of coat in accordance with the direction taken by SM-II (Fig. $1 \mathrm{H}$, Photo 4, Table 1).

SM-II begins, under the conditions prevailing at Białowieża, in principle in the third ten-day period of April (one specimen in the second ten-day period) and lasts until the end of May. In successive decades of May 25, 38 and $26 \%$ of all the shrews caught durind this period were moulting (Fig. 2). Its duration in the population is the same as for SM-I, i.e. about six weeks. The intensivity of this moult expressed in the percentage of individuals moulting in relation to all the animals caught, is also similar. With both moult I and II from $30-40 \%$ individuals change hair in this way during the peak phase. 
SM-II was mainly observed in males. This is probably due to the distribution of numbers of individuals of the two sexes in the material. Of the 69 individuals undergoing SM-II only 8 were females, none of which changed hair from spring to summer coat, but only from winter to summer (?). This is undoubtedly the result of their rearing the young and their consequent low trappability of the females. It is clear that females must undergo SM-II, since our material contained some with spring hair, and later with summer hair (cf. Table 1, columns 8 and 13).

Among all the individuals changing coat according to the SM-II type $(\mathrm{n}=69) 17$ individuals were found $(25 \%)$ in which the secondary (?) 6-segment winter hair probably changed directly into the 4-segment summer hair (Table 1, column 9). It may be assumed that at least some of these individuals obtained winter hair again as the result of SM-I. Confirmation of this is provided by the following facts: (1) Several cases were observed in captive animals ( 4 S. araneus and $1 S$. minutus) when the moult of 6-segment winter hair was followed by growth of a winter coat of the same length (B or ow sk i, 1964 and unpublished observations from the spring of 1967). (2) One individual was obtained by trapping on April 7th 1954 which had winter hair on a light-coloured skin, corresponding in thickness $(157 \mu)$ to spring or summer skin, i.e. following the spring moult. It would seem less probable, although there are no grounds for completely excluding this possibility, that these shrews changed coats only once, directly from winter to summer, but in the direction proper to SM-II.

\section{DISCUSSION}

\section{Course of the spring moult}

The most important fact established by the present investigations is that in Sorex araneus at Białowieża there are two spring moults differing in the direction they take over the animal's skin, i.e. from the belly to the back and from the back to the belly. Both directions have in fact been given by many authors in describing the course taken by the spring moult in different representatives of Soricidae. P o pov (1960) and $\mathrm{Sk}$ a ré $\mathrm{n}$ (1964) state that the spring moult begins on the ventral side, and ends on the dorsal side. Others consider that this moult proceeds in exactly the opposite direction (D e hnel, 1949; C r o w c r of t, 1955, 1957; Findle y \& J ones, 1956). In the light of the results obtained it may be gathered that in the first case it was SM-I which was observed, and in the second - SM-II.

Spring moults I and II may take place at once over the whole of the animal's skin (total moult), or only within a narrow belt of skin (wave 
moult). It is relatively easy to trace the direction of moult from back to belly or vice versa in the case of the wave moult. With SM-I the shorter hair occurs from the ventral side and from the front, the longer hair - from the dorsal side. The reverse applies to SM-II.

The direction of moult is more difficult to distinguish in the case of total moult, when new hair begins to grow under the long hair over the whole of the mammal's body. Observations made under a binocular microscope make it possible to establish whether the process of growth of the new hair is more advanced on the back or belly, of course always in relation to the normal length of hair in these parts of the body. The difference in length of the new hair on back and belly thus indicates

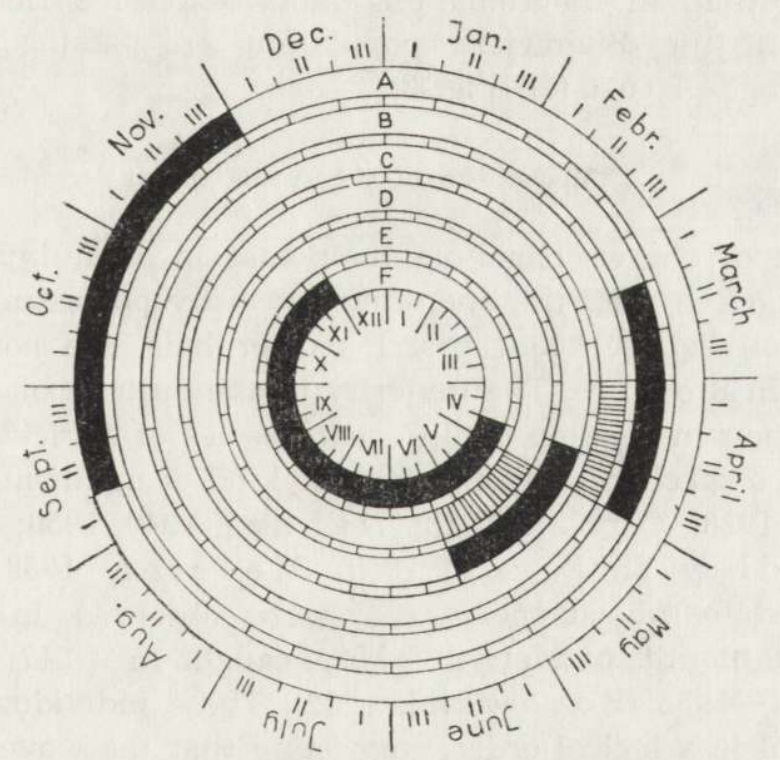

Fig. 3. Times of moult in Sorex araneus at Białowieża (1947-1964).

the direction in which the moult is proceeding on the animal's skin. This means of differentiation is of particular importance in the case of shrews moulting from 6-segment secondary winter hair to 4-segment summer hair. When a shrew with 6 -segment hair is held into the hand in the late spring (end of April, May) the impression is gained that the mammal is moulting for the first time. The more advanced growth of the new hair on the back than on the belly then shows that SM-II is in process, i. e. moult from back to belly. In addition a shrew which is not moulting but has long hair at this time has skin approximately $50 \%$ thicker than the winter skin, which indicates that it has passed through SM-I (Table 2). 
Among the captive shrews there were individuals (Borowski, 1964) in which SM-I began on the back. They changed thair coat straight away to the summer one and SM-II was not observed to occur in them at all. A deviation of this kind from the natural conditions at Białowieża points to the great physiological adaptability of the organism of these animals and is undoubtedly caused by the artificial conditions under which they are kept.

Generally speaking in Sorex araneus, and probably in other species of this genus, after the young have left the nest 4 moults occur during the life cycle: an autumn, two spring and a senile moult. As a result it is only from December to February that there are no moulting shrews in the population. In the remaining months more or less individuals, at any rate in the Białowieża population, are passing through some phase of change of coat (cf. Fig. 3).

\section{Mechanism of the spring moult}

Description of shrews changing their coat in an untypical way, i.e. without changes in the skin, and simultaneously possessing a sharp line of demarcation between longer and shorter hair, are not infrequently encountered in literature. The majority of the authors of earlier studies on this question in relation to different species of Soricidae interpreted such cases as a specific, or even "normal « kind of moult in these animals (J a ck s o n, 1928; O g nev, 1928; D e hne l, 1949, 1950; H a milt o n, 1940,; Findley \& Jones, 1956; Me ester, 1958; Wiliams, 1962). Such states of change of coat were observed in all moulting shrews in the months of March - May, caught $(\mathrm{n}=247)$ at Białowieża between 1947-1952 (B or ow sk i, 1952). These individuals could have been arranged in a logical order, suggesting that the wave of shortenins of the hair (»reduction") proceeds once from the ventral side to the back and the second time - from the back to the belly. In the preliminary report referred to (Borowski, 1952) the hypothesis was put forward that the mechanism of the spring change of coat consists nct in the growth of new - shorter hair, but in the shortening, occurring twice, of the same winter hair by breaking off the end segments. This was criticized by later authors ( $\mathrm{S} \mathrm{te}$ i n, 1954; S c h w a r z, 1955; P cpov, 1960), who had single specimens of shrews in the stage of normal spring moult, with black patches on the skin in their collection. They considered the cases described of longer and shorter hair withot changes in the skin as interrupted moult.

The material presented in the present study (Table 1, columns 7 and 12) permits of confirming this view in respect of Sorex araneus and 
assuming that the majority of the earlier descriptions of other species of the Soricidae familly refer to interrupted SM-I or SM-II. New data indicate that in case of shrews there are two moults in the spring, differing in respect of the direction in which they proceed, which agrees with earlier observations (Borowski, 1952). The fact that the percentage of individuals with interrupted moult is relatively great, gives cause for reflection. In material from 1947-1952 I had only such individuals, forming $35 \%$ of the material from the months of MarchMay, at my disposal. In material for the period 1953-1964 this percentage was $14 \%$ in relation to all the individuals caught and $34 \%$ in relation to all the animals changing winter hair to summer.

It would appear that this may depend on the capture method used. The permanent trapping areas used from 1947-1952 mainly trapped migrating individuals. It may however be assumed that the activity of movements of shrews in process of moulting, with 4-5 times thicker skin, may be limited, and therefore their chances of being caugth are smaller. The later use (1953) of traps of different kinds, set under uprooted tree stumps for short periods in different places, yielded numerous material, which included a certain percentage of moulting individuals. The actual process of moulting lasted for a relatively short time. Individual observations have shown that the shrew can change its hair within two or five days (W il cke, 1938; B or ow ski, 1964). There is thus little chance of catching moulting individuals.

\section{Are spring moults in shrews an expression of adaptation process?}

The presence of two spring moults in the common shrew is an unusual phenomenon. It is difficult at the present time to explain the biological reason for two spring moults, involving considerable expediture of energy within a short period of time. It may, however, be assumed that this is some specific form of adaptation of these small mammals to living in areas in which winter conditions (snow cover, low air temperatures) persist for a relatively long time, with simultaneous significant lengthening of daylight. Under such conditions of a longer but cold day it might be advantageous to continue with the longer fur (winter or spring). If this assumption is true, we should have more individuals changing the true winter coat, according to SM-II type, in years when the winter is prolonged. Both these variants are, of course, physiologically possible and have been observed under laboratory conditions, and may be very probably found also in the nature (cf. B orow ski, 1964, and Table 1, columns 4 and 9). 
In order to check this hypothesis comparisons were made of the percentages of individuals changing true winter coat to secondary winter (?) coat (Table 1, column 4) and secondary winter (?) coat directly to summer coat (Table 1, column 9) in relation to all the shrews moulting in three categories of years: (1) Years with an early spring, beginning about March 1st (1953, 1959, 1961), (2) Years with average spring, beginning about March 15th (1954, 1957, 1960) and (3) Years with a late spring, beginning about April 1st (1955, 1956, 1958, 1962, $1963,1964)$. No significant differences were observed in the percentage of the above-mentioned individuals in different groups of springs. On account of the scantiness of material, however, this result does not completely refute the assumption made. The problem requires further investigation on the basis of more representative collections from the spring period. It would be particularly interesting here to obtain a good knowledge of the course taken by the spring change of coat in shrews living in different climatic zones coming with the geographic range of these animals.

Acknowledgments: I should like to take this opportunity of expressing my grateful thanks to Dr. Zdzisław $\mathrm{Pucek}$ for his constructive critical comments during the elaboration of the material and preparing the manuscript.

\section{REFERENCES}

1. B or owski S., 1952: Sezonowe zmiany uwłosienia u Soricidae. Annls Univ. M. Curie-Skłodowska, Sect. C 7, 2: 65-117, Lublin.

2. B or owski S., 1959: Variations in density of coat during the life cycle of Sorex araneus araneus L. Acta theriol., 2, 14: 286-289.

3. Borowski S., 1963: Old-age moult in the Common shrew, Sorex araneus L in na e us, 1758. Acta theriol., 7, 19: $374-375$.

4. B or ow ski S., 1964: Moult of Shrews (Sorex L.) under laboratory conditions. Acta theriol., 8, 8: 125-135.

5. Borowski S. \& Dehnel A., 1953: Materialy do biologii Soricidae. Annls Univ. M. Curie-Skłodowska, Sect. C 7, 6: 305-448. Lublin.

6. Cerevitinov B. F., 1958: Topografičeskije osobennosti volosianogo pokrova pušnych zverej. Tr. Vses. N.-i. In-ta životn. syria i pušniny, 17: 256-307.

7. Crowcroft P., 1955: Remarks on the pelage of the Common Shrew (Sorex araneus L.). Proc. zool. Soc., London, 125, 2: 309-315.

8. Crowcroft P., 1957: The life of the Shrew. M. Reinhard: 1-166. London.

9. Dehne1 A., 1949: Studies on the genus Sorex L. Annls Univ. M. Curie-Skłodowska, Sect., C 4, 2: 17-102. Lublin.

10. Dehnel A., 1950: Studies on the genus Neomys Ka u p. Annls Univ. M. Curie-Skłodowska, Sect., C 5, 1: 1-63. Lublin.

11. F indle y J. S. \& J on es J. K., 1956: Moult of the Short-tailed shrew, Blarina brevicauda. Amer. Midl. Natur., 56, 1: 246-249.

12. Hamilton W. J., 1940: The moult of Blarina brevicauda. J. Mammal., 21, 4: $457-458$. 
13. J a cks on H. H. T., 1928: A taxonomic review of the American longtailed Shrews. North Amer. Fauna, 51: 1-30. Washington.

14. Meester J., 1958: The fur and moults in the shrew, Myosorex cafer. J. Mammal., 39, 4: 494-498.

15. Ognev S. I., 1928: Zvery vostočnoj Evropy i severnoj Azji. Insectivora. 1: $1-631$. Moskva.

16. Popov V. A., 1960: Mlekopitajuščije Volžsko-Kamskogo Kraja. Kazanskij Filial AN SSSR: 1-466. Kazan'.

17. Pucek Z., 1959: Some biological aspects of the sex-ratio in the Common shrew (Sorex araneus araneus L.). Acta theriol., 3, 4: 43-73.

18. Pucek Z., 1963: Seasonal changes in the braincase of some representatives of the genus Sorex from the Palearctic. J. Mammal., 44, 4: 523-536.

19. Skarén U., 1964: Variation in two shrews, Sorex unguiculatus Dobson and S. a. araneus L. Ann. Zool. Fenn., 1, 2: 94-124.

20. Spitzenberger F. H., 1966: Uber die makroskopische Ausbildung der Seitendrüsen bei der Waldspitzmaus (Sorex araneus L.). Zool. Anz., 177: 329333.

21. S chwarz S. S., 1955: Biologia zemlerojek lesostepnogo zauralija. Zool. Ž., 34, 4: $915-927$.

22. Stein G. H. W., 1954: Materialen zum Haarwechsel deutschen Insectivoren. Mitt. zool. Mus. Berlin, 30, 1: 12-34.

23. Toldt K., 1935: Aufbau und natürliche Färbung des Haarkleides der Wildsäugetiere. Deutche Gesellschaft für Kleintier- und Pelztierzucht G. m. b. H. \& Co.: 1-291. Leipzig.

24. Wilcke G., 1938: Freilands- und Gefangenschaftsbeobachtungen an Sorex araneus L. Z. Säugetierkde, 12: 332-335.

25. W illiam s L. W., 1962: Moult in Blarina brevicauda. J. Mammal., 43, 3: $423-424$.

Received, May 28, 1968.

Mammals Research Institute,

Polish Academy of Sciences,

Białowieża, Poland.

EXPLANATION OF PLATE XIV

Photo 1. Total spring moult I from skin side.

Photo. 2. Wave spring moult I from skin side.

Photo 3. Irregular course of wave spring moult I.

Photo 4. Interrupted spring moult II from side of skin and hair. 
Stanisław BOROWSKI

\section{O LINCE U RYJÓWKI AKSAMITNEJ}

\section{Streszczenie}

W oparciu o liczne materialy $(n=905)$ z miesięcy wiosennych (marzec - czerwiec 1953-1964) wykazano, iż u ryjówki aksamitnej, Sorex araneus L in na e us, 1758, mamy do czynienia z dwoma linkami wiosennymi różniącymi się charakterem, czasem i kierunkiem przebiegu (Ryc. 1).

Linka wiosenna I polega na zmianie włosa zimowego 6-członowego na wiosenny 5-członowy i przebiega od spodu ciała na grzbiet. Linka wiosenna II zmienia włos wiosenny na letni 4-członowy i zaczyna się na grzbiecie, a kończy się po stronie brzusznej zwierzęcia. Kierunek obu linek jest zgodny z obserwacjami różnych autorów, którzy opisywali bądź tylko pierwszą, bądź tylko drugą linkę wiosenną. Pośrednio stadia przerwanej linki I, lub II, określane wcześniej mianem „wiosennej redukcji włosa" (B o r owski, 1952) są również zgodne z kierunkiem przebiegu obu linek wiosennych. Linki wiosenne przerwane obserwowano u dość dużego procentu osobników w populacji: pierwszą u $40 \%$, drugą u $22 \%$. (Rys. 2).

Obie zmiany włosa mogą mieć postać linki całkowitej, obejmującej całą skórę, lub większe jej partie, albo też linki falowej, polegającej na zmianie uwłosienia tylko w obrębie wąskiego pasa skóry.

Linka wiosenna I rozpoczyna się w Puszczy Białowieskiej w drugiej dekadzie marca, a kończy się zasadniczo w trzeciej dekadzie kwietnia. Linka wiosenna II rozpoczyna się właściwie dopiero w trzeciej dekadzie kwietnia i trwa do pierwszej dekady czerwca (Ryc. 3). Samce linieją wcześniej niż samice.

Zmiany grubości skóry, oraz długości włosa w różnych sezonach, a także wcześniejsze obserwacje hodowlane pozwalają pośrednio przypuszczać, że w niektórych przypadkach ryjówki mogą zmieniać wiosną włos zimowy 6-członowy na wtórny zimowy o takiej samej długości. Wśród ryjówek zmieniających włos według typu linki wiosennej II było $25 \%$ osobników, które liniały wprost z włosa zimowego prawdopodobnie na letni. 


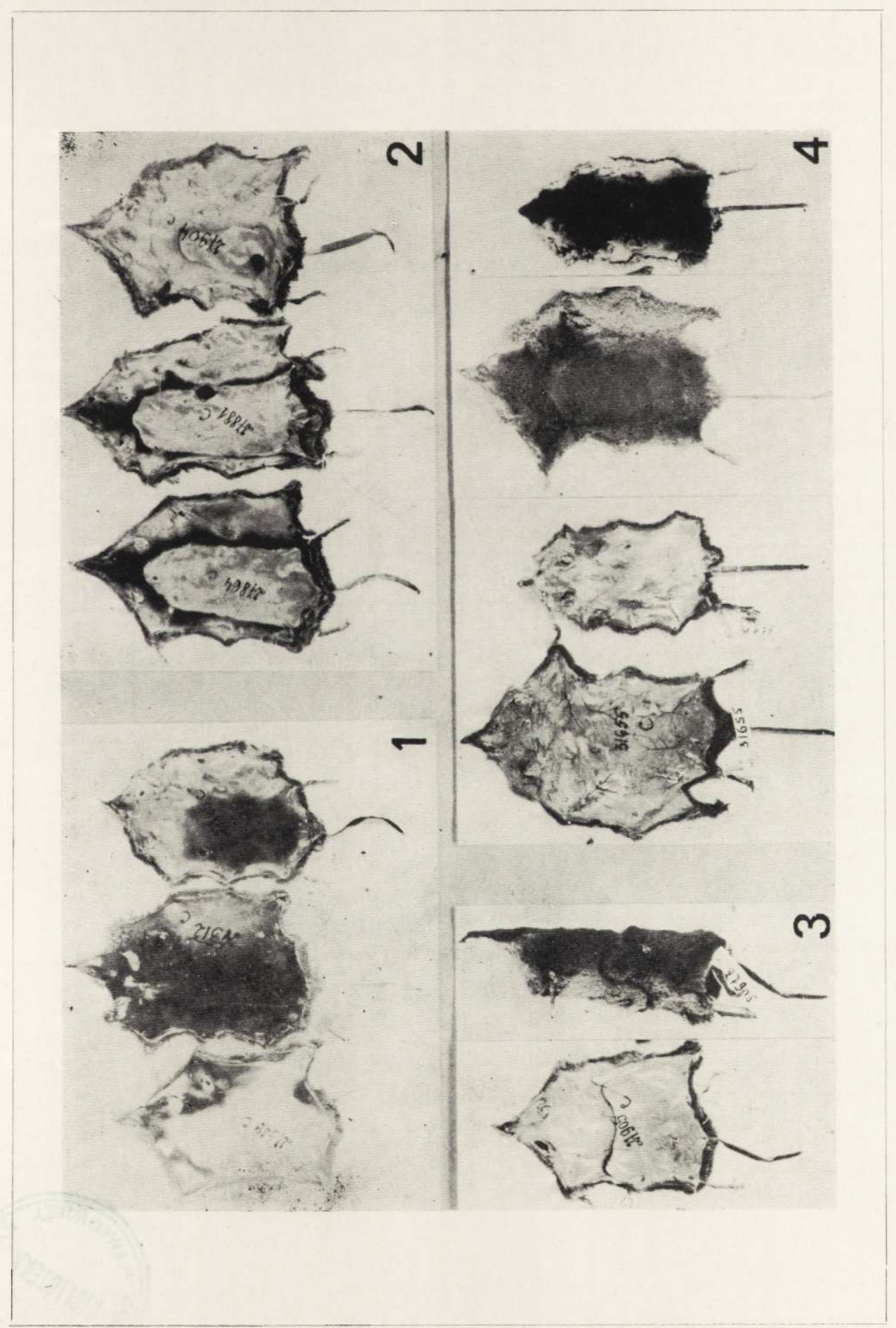

